\title{
Platelet aggregating activity in serum from patients with HLA-B27 associated rheumatic and cardiac disorders: a possible link to the proliferative vascular changes
}

\author{
Lennart Bergfeldt, Olof Edhag, Göran Holm, Renée Norberg
}

\begin{abstract}
Objective-To search for possible serum factors (immunochemical abnormalities) that reflect HLA-B27 associated inflammatory process with the proliferative endarteritis, which is an important cause of severe bradycardia and aortic valve regurgitation.

Patients and methods-Seventy four men with pacemakers were studied: 24 were HLA-B27 positive and had associated rheumatic and cardiac disorders, 13 were B27 positive but had no clinical or radiographic signs of a related rheumatic condition, and 37 were B27 negative controls. Randomly obtained serum samples were examined for a series of serum factors.
\end{abstract}

Results-Thirteen (57\%) of the 23 patients with HLA-B27 and associated rheumatic and cardiac conditions had platelet aggregating activity in their serum. No such activity was found in sera from patients in the other groups. None the less, immunochemical abnormalities were common among patients of all groups; $30(41 \%)$ had antinuclear antibodies or rheumatoid factor or both.

Conclusion-The platelet aggregating activity found in patients with HLA-B27 and associated rheumatic and cardiac conditions may reflect serum factors that increase the stickiness of platelets and increase their adhesion to the vessel wall. This suggests a link via release of platelet derived growth factor(s) with the characteristic histopathological feature of proliferative endarteritis. Immunochemical abnormalities were common in serum from all men with pacemakers.

The HLA-B27 allele is associated with a predisposition to seronegative spondarthritides and impairment of the cardiac conduction system, ${ }^{1-3}$ the aortic and mitral valves, ${ }^{4-7}$ and the myocardium. ${ }^{89}$ The most common and clinically important cardiac disorders are complete heart block and aortic valve regurgitation. A substantial proportion $(15-20 \%)$ of men with pacemakers ${ }^{31011}$ (but not women ${ }^{12}$ ) and of white patients with aortic valve regurgitation have the HLA-B27 allele. ${ }^{13-15}$ The histopathological features of the disease process include perivascular infil- tration of inflammatory cells around small vessels such as the vasa vasorum of the proximal aorta and around vessels in the interventricular septum and vessels adjacent to the affected joints. The lumens of these vessels are obliterated by endothelial and fibromuscular proliferation (endarteritis obliterans). ${ }^{1516}$

In the present study we looked for immunochemical factors in the serum that could be linked to the proliferative vascular disease in HLA-B27 positive patients.

\section{Patients and methods}

PATIENTS

We studied men with pacemakers who had been examined for HLA-B27 associated rheumatic disorders. ${ }^{3011}$ When the history was taken we noted any signs or symptoms that might have been linked with HLA-B27 such as acute anterior uveitis, low back pain, arthritis or arthralgia, psoriasis, inflammatory bowel disease, and urogenital infection or discharge. The sacroiliac joints in all patients in the three groups had been $x$ rayed, and patients with confirmed sacroiliitis were also examined for spondylitis. We used the 1966 New York criteria for ankylosing spondylitis and sacroiliitis was diagnosed only when we found radiographic changes of grade 2 (definite changes) to $4 .{ }^{17}$ The patients' HLA type was determined by a standard microlymphocytotoxicity test. ${ }^{18}$

Group 1-We studied 24 HLA-B27 positive men (mean age 74 years, range 36-91) with rheumatic and cardiac syndromes. Ankylosing spondylitis was present in 14 patients (five also had had uveitis). Five patients had sacroiliitis or typical spondylitis (two with uveitis). In five patients peripheral arthritis and/or uveitis dominated. Twenty patients had a pacemaker because of second and third degree atrioventricular block. Four patients had other bradycardias, mainly sinus node disease with or without supraventricular tachycardias. Thirteen patients had regurgitant aortic valves, which in three had been replaced. Four patients had a history of myocardial infarction.

Group 2 consisted of 13 HLA-B27 positive men (mean age 79, range 59-90) with complete heart block but without any clinical or radiographic evidence of a rheumatic disorder. 
Group 3 was the control group of 37 men (mean age 76, range 39-91) with complete heart block. They were all HLA-B27 negative and had no radiographic signs of sacroiliitis.

\section{BLOOD TESTS}

We collected blood samples when the patients came for routine examination of their pacemaker systems. Blood was drawn at room temperature. Blood for cryoglobulin determination was immediately transferred to a centrifuge and the serum was separated at $37^{\circ} \mathrm{C}$. Serum samples were stored at $-70^{\circ} \mathrm{C}$.

\section{ANALYTICAL METHODS}

C reactive protein, orosomucoid, antichymotrypsin, and complement factors C3 and $\mathrm{C} 4$ were measured by the Laurell rocket electrophoresis technique. ${ }^{19}$ IgG, IgA, and IgM concentrations were measured on commercial immunodiffusion plates (Behringewerke, Marburg, Germany). Complement activation via the classical and alternative pathways was assessed by haemolysis-in-gel methods. ${ }^{20}$ Rheumatoid factor was detected by the Waaler-Rose test. Antinuclear antibodies, antimitochondrial antibodies, and smooth muscle antibodies were measured by a standard indirect immunofluorescent technique. In patients with antinuclear antibodies we used the Crithidia lucilliae method to detect anti-DNA antibodies. Antibodies to extractable nuclear antigens were analysed by counter immunoelectrophoresis. ${ }^{21}$

Circulating soluble immune complexes were assayed by a solid phase Clq-binding enzyme linked immunoadsorbent assay (ELISA), ${ }^{22}$ and a solid phase conglutinin binding ELISA. ${ }^{23}$ We used Myllylä's platelet aggregation test. ${ }^{24} \mathrm{~A}$ titre $\geqslant 1 / 8$ was regarded as abnormal; though 99 of 100 healthy blood donors had a titre $\leqslant 1 / 4.25$

\section{STATISTICAL ANALYSIS}

We used Fisher's exact test to determine the statistical significance of differences between groups.
The study was approved by the Medical Ethics Committee of the Karolinska Institute and the patients gave their informed consent.

\section{Results}

The platelet aggregation test was positive in 13 $(57 \%)$ out of 23 of the patients in group 1, though two had a titre $1 / 4$ that is occasionally seen in healthy controls. None of the patients in groups 2 and 3 had a positive platelet aggregation test (group $1 v$ group $2, \mathrm{p}<0.001$; group 1 $v$ group $3, \mathrm{p}<0.001$ ). All five of the 13 patients with a positive platelet aggregation test with titres $>1 / 4096$ had aortic regurgitation.

Serum from six $(26 \%)$ of the group 1 patients contained cryoglobulins. None of the patients in the other groups was positive (group $1 v$ group $2, \mathrm{p} \leqslant 0.05 ;$ group $1 v$ group 3 , $\mathrm{p}<0.01$ )

The assay for $\mathrm{Clq}$ was positive in one patient in group 1 and in two patients in group 2. The conglutinin test was positive in two patients in group 1 but not in any patients in groups 2 and 3.

Serological signs of inflammatory activity, such as increases in sedimentation rate and other acute phase reactants including C3 and $\mathrm{C} 4$, were common in all groups (table). But there were no clear cut differences between the three groups or any association between the presence of platelet aggregating activity and an increase in acute phase reactants.

We found autoantibodies in 31 of the 74 patients. Rheumatoid factor, mostly in low titre, was found in all groups: in seven $(29 \%)$ of 24 in group 1 , in one out of 13 in group 2 , and in seven $(19 \%)$ of 37 in group 3 . Antinuclear antibodies were present in four $(17 \%)$ (all $\leqslant 1 / 25)$ of 24 in group 1 , in three $(23 \%)$ (two $\geqslant 1 / 100$ ) of 13 in group 2 , and in $12(32 \%)(7 \geqslant 1 / 100)$ of 37 in group 3 . Though antinuclear antibodies were more common and were found in much higher titres in group 3 than in group 1, the difference was not significant. We did not find DNA antibodies or antibodies directed against extractable nuclear antigens in any patient. A patient with chronic

Results of blood tests in the three groups of patients with pacemakers

\begin{tabular}{|c|c|c|c|c|}
\hline Variable & $\begin{array}{l}\text { Group 1 } \\
(n=24) \\
B 27+\mid R S+\end{array}$ & $\begin{array}{l}\text { Group 2 } \\
(n=13) \\
B 27+\mid R S-\end{array}$ & $\begin{array}{l}\text { Group } 3 \\
(n=37) \\
B 27-\mid R S-\end{array}$ & $p$ \\
\hline $\begin{array}{l}\text { ESR }>15 \mathrm{~mm} / \mathrm{h} \\
\text { Leucocytes }>9.0 \times 10^{9} / 1 \\
\text { Abnormal differential count } \\
\text { CRP } \geqslant 0.01 \mathrm{mg} / \mathrm{ml} \\
\text { Orosomucoid } \geqslant 1.0 \\
\text { Antichymotrypsin } \\
\text { C3 (increased) } \\
\text { C4 (increased) } \\
\text { RF } \\
\text { ANA } \\
\text { Mitochondrial antibodies } \\
\text { Smooth muscle antibodies } \\
\text { Cryoglobulins }\end{array}$ & $\begin{array}{l}9 / 20 \\
4 / 21 \\
5 / 21(3) \\
6 / 24 \\
4 / 24 \\
4 / 24 \\
4 / 24 \\
5 / 24 \\
7 / 24 \\
4 / 24 \\
0 / 23 \\
0 / 23 \\
6 / 23\end{array}$ & $\begin{array}{l}6 / 11 \\
3 / 11 \\
4 / 12(2) \\
1 / 13 \\
3 / 13 \\
2 / 13 \\
0 / 13 \\
0 / 13 \\
1 / 13 \\
3 / 13 \\
0 / 13 \\
0 / 13 \\
0 / 13\end{array}$ & $\begin{array}{l}8 / 29 \\
4 / 33 \\
9 / 31(4) \\
3 / 19 \\
6 / 37 \\
4 / 37 \\
1 / 37 \\
3 / 37 \\
7 / 37 \\
12 / 37 \\
1 / 37 \\
3 / 37 \\
0 / 36\end{array}$ & 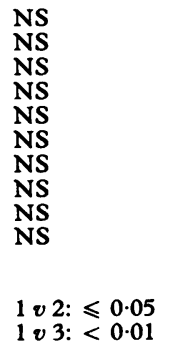 \\
\hline $\begin{array}{l}\text { Clq-ELISA } \\
\text { Conglutinin } \\
\text { PLA }\end{array}$ & $\begin{array}{l}1 / 23 \\
2 / 23 \\
13 / 23\end{array}$ & $\begin{array}{l}2 / 13 \\
0 / 13 \\
0 / 13\end{array}$ & $\begin{array}{l}0 / 35 \\
0 / 35 \\
0 / 37\end{array}$ & $\begin{array}{l}1 v 2:<0.001 \\
1 v 3:<0.0001\end{array}$ \\
\hline
\end{tabular}

Fisher's exact test was used

*Figures in parentheses are eosinophils.

ANA, antinuclear antibodies; C, complement factor; CRP, C-reactive protein; ESR, erythrocyte sedimentation rate; PLA, platelet aggregation test; RF, rheumatoid factor. 
liver disease in group 3 had mitochondrial antibodies (titre $\geqslant 1 / 1600$ ).

\section{Discussion}

Since 1973 when the association between HLA-B27 and ankylosing spondylitis was reported, ${ }^{2627}$ a link has been sought between HLA-B27 and the histopathological features and clinical characteristics of the HLA-B27 associated rheumatic disorders.

Our results were unremarkable and consistent with other studies of patients with ankylosing spondylitis. There are, however, three observations of interest. First, we found platelet aggregating activity in $57 \%$ of the patients with HLA-B27 associated disorders (group 1) but not in the other groups. This is an original observation. We used platelet aggregating activity to search for circulating immune complexes. Norberg found platelet aggregating activity in 36 out of 171 patients with rheumatoid arthritis. ${ }^{28}$ This activity was probably due to the presence of circulating immune complexes. ${ }^{28}$ In our study, however, only three patients with the rheumatic and cardiac syndromes had positive $\mathrm{Clq}$-binding or conglutinin tests, suggesting circulating immune complexes, and two of them had no platelet aggregation. Furthermore, platelet aggregating activity was not associated with an increase in acute phase reactants, which were normal in eight of the 13 patients with platelet aggregating activity. Neither was there a relation with increased immunoglobulin concentrations, which were found in only two of the 24 patients in this group.

Our observations need to be confirmed by other in vitro and in vivo tests of platelet aggregation and the cause of this activity must be elucidated. In theory, the platelet aggregating activity could be related to serum factors that can increase the stickiness of platelets and facilitate their adhesion to the vessel wall. ${ }^{29}$ Platelet derived growth factor locally released by activated or damaged platelets may be involved in the intimal proliferation that has been found in patients with HLA-B27 associated disease. ${ }^{15716} \mathrm{~A}$ similar process may lead to vascular proliferative lesions in different diseases. ${ }^{30}$

Serum samples from six of the HLA-B27 positive patients with rheumatic and cardiac disease also contained cryoglobulins. Mixed cryoglobulins are commonly encountered in various types of vasculitic disorders, ${ }^{31}$ but none of our patients had clinical or immunological signs supporting a diagnosis of systemic lupus erythematosus or other autoimmune diseases. Two patients with cryoglobulins gave a history of Raynaud-like symptoms, however.

We found that immunochemical abnormalities were common in all groups. This accords with a recent report of antinuclear antibodies in $54 \%$ of 65 patients with atrioventricular block and in $47 \%$ of 45 patients with sick sinus syndrome, all of them with pacemakers. ${ }^{32}$

We based the diagnosis of rheumatoid disease in patients with the HLA-B27 allele on the presence of one or more of the most typical clinical manifestations: radiographically verified sacroiliitis, Reiter's disease, and acute anterior uveitis. We grouped the HLA-B27 associated syndromes together because of $(a)$ the considerable clinical overlap in individuals and within families; $(b)$ the various disease manifestations or tissue disorders show separate association with HLA-B27 $7^{33-35}$; (c) the similarity of the heart manifestations in patients with different B27 associated rheumatic and ocular disorders, and the fact that in white men the combination of clinically significant bradycardia and pure aortic valve regurgitation is basically an HLA-B27 associated syndrome with $88 \%$ of the patients being HLA-B27 positive ${ }^{315}$; (d), and histopathological changes are similar in periarticular and non-articular tissues. ${ }^{516}$ None the less, the HLA-B27 allele is not a diagnostic criterion in the disorders listed above, and disease processes not associated with HLA-B27 may lead to similar clinical manifestations. All the patients in group 1 had the rheumatic and/or ocular manifestations associated with HLAB27. Six of seven patients with rheumatoid factor in group 1 had radiographically confirmed sacroiliitis or spondylitis or both. The seventh patient had a titre $1 / 20$. Furthermore, other criteria of rheumatoid arthritis were not found in these patients. We therefore firmly believe the rheumatoid factor was coincidental. Presumably the disease process associated with HLA-B27 was also the underlying cause of the cardiac disease in these patients. No other cause was found, and there was histopathological evidence to support this assumption in three patients. ${ }^{7}$

We cannot regard the presence of cardiac disorders as evidence of a particularly severe inflammatory process in our patients because the severity of joint disease does not parallel the cardiac manifestations. ${ }^{315}$ Furthermore, because up to $20 \%$ of patients with ankylosing spondylitis have either high degree atrioventricular block or aortic regurgitation, ${ }^{3637}$ earlier studies of immunochemical serum factors must surely have included patients with these cardiac manifestations.

We thank Professor C Kjellstrand for constructive criticism This study was supported by grants from the Professor Nann Svartz Foundation, the Swedish Heart-Lung Foundation, and the Karolinska Institute.

1 Weed CL, Kulander BG, Mazzarella JA, Decker JL. Heart block in ankylosing spondylitis. Arch Intern Med 1966;117:800-6.

2 Kinsella TD, Johnson LG, Sutherland RI. Cardiovascular manifestations of ankylosing spondylitis. Can Med Assoc J 1974;111:1309-11.

3 Bergfeldt L. HLA B27-associated rheumatic diseases with severe cardiac bradyarrhythmias. Clinical features and prevalence in 223 men with permanent pacemakers. Am Med 1983;75:210-5.

4 Paulus HE, Pearson PM, Pitts W Jr. Aortic insufficiency in five patients with Reiter's syndrome. A detailed clinical and pathologic study. Am J Med 1972;53:464-72.

5 Bulkley BH, Roberts W C. Ankylosing spondylitis and aortic regurgitation. Description of the characteristic lesion from study of eight necropsy patients. Circulation 1973 48:1014-27.

6 Roberts WC, Hollingsworth JF, Bulkley BH, Jaffe RB, Epstein SE, Stinson EB. Combined mitral and aortic regurgitation in ankylosing spondylitis. Angiographic and anatomic features. Am J Med 1974;56:237-43.

7 Bergfeldt L, Edhag O, Rajs J. HLA-B27-associated heart 
disease. Clinico-pathologic study of three cases. Am J Med 1984;77:961-7.

8 Ribeiro P, Morley KD, Shapiro LM, Garnett RAF, Hughes GRV, Goodwin JF. Left ventricular function in patients with ankylosing spondylitis and Reiter's disease. patients with ankylosing spo

9 Brewerton DA, Goddard DH, Moore RB, et al. The myocardium in ankylosing spondylitis. A clinical, echocardiographic, and histopathological study. Lancet 1987;i:995-8.

10 Bergfeldt L, Edhag O, Vedin L, Vallin H. Ankylosing spondylitis: an important cause of severe disturbances of the cardiac conduction system. Prevalence among 223 pacemaker-treated men. Am J Med 1982;73:187-91.

11 Bergfeldt L, Möller E. Complete heart block-another HLA B27 associated disease manifestation. Tissue Antigen 1983;21:385-90.

12 Bergfeldt L, Möller E. Pacemaker treated women with heart block have no increase in the frequency of HLA-B27 and associated rheumatic disorders in contrast to men-a sex associated rheumatic disorders in contrast to men-a sex
linked difference in disease susceptibility. $J$ Rheumatol 1986;13:941-3.

13 Tan PLJ, Butler MJ, Woodfield DG, Jacobson C Grigor RR, Caughey DE. HLA antigens in isolated aortic incompetence [Letter]. J Rheumatol 1980;7:757-9.

14 Qaiyumi S, Ul Hassan Z, Toone E. Seronegative spondyloarthropathies in lone aortic insufficiency. Arch Inter Med 1985;145:822-4.

15 Bergfeldt L, Insulander P, Lindblom D, Möller E, Edhag O. HLA-B27: an important genetic risk factor for lone aorti regurgitation and severe conduction system abnormalities. Am J Med 1988;85:12-8.

16 Engfeldt B, Romanus R, Ydén S. Histological studies of pelvospondylitis ossificans (ankylosing spondylitis) correlated with clinical and radiological findings. $A n n$ Rheum Dis 1954;13:219-28.

17 Bennett PH, Wood PHN, eds. Population studies of the rheumatic disease. Proceedings of the 3rd international symposium, New York, 1966. Amsterdam: Excerpta symposium, New York,
Medica, 1968: 314-6, 456-7.

18 Kissmeyer-Nielsen F, Kjerbye KE. Lymphocytotoxic micro-technique: purification of lymphocytes by flotation. In: Histocompatibility testing. Copenhagen: Munksgaard, 1967: 381-4.

19 Laurell CB. Qualitative estimation of proteins by electrophoresis. Ann Biochem 1966;15:45-52.

20 Truedsson L, Sjöholm AG, Laurell AB. Screening for deficiencies in the classical and alternative pathways of complement by hemolysis in gel. Acta Pathol Microbiol Scand C 1981;89:161-6.

21 Sharp GC, Irvin WS, Tan EM. Mixed connective tissue disease-an apparently distinct rheumatic disease syndrome associated with a specific antibody to an extractable nuclear antigen (ENA). Am J Med 1972;52:148-59.

22 Hay FC, Nineham LJ, Roitt IM. Routine assay for the detection of immune complexes of known immunoglobulin class using solid phase C1q. Clin Exp Immunol 1976;24:396-400.

23 Casali P, Bossus A, Carpentier AN, et al. Solid-phase enzyme immunoassay or radioimmunoassay for the detection of immune complexes based on their recognition by conglutinin: conglutinin binding test. Clin Exp Immunol conglutinin: conglu

24 Myllylä G. Aggregation of human blood platelets by immune complexes in the sedimentation pattern test. Scand J Haematol 1973;suppl 19:1-56.

25 Hedfors E, Norberg R. Evidence for circulating immune complexes in sarcoidosis. Clin Exp Immunol 1974;16: 493-6.

26 Brewerton DA, Caffrey M, Hart FD, James DCO, Nicholls A, Sturrock RD. Ankylosing spondylitis and HL-A27. Lancet 1973;i:904-7.

27 Schlosstein L, Terasaki PI, Bluestone R, Pearson CM. High association of an HL-A antigen, W27, with ankylosing spondylitis. N Engl J Med 1973;288:704-6.

28 Norberg R. IgG complexes in serum of rheumatoid arthritis patients. Scand J Immunol 1974;3:229-36.

29 Ross R. The pathogenesis of atherosclerosis-an update. N Engl J Med 1986;314:488-500.

30 Rubin K, Hansson GK, Rönnstrand L, et al. Induction of B type receptors for platelet-derived growth factor in vascular inflammation: possible implications for develop ment of vascular proliferative lesions. Lancet 1988;i: 1353-6.

31 Cream JJ. Clinical and immunological aspects of cutaneous vasculitis. $Q J$ Med 1976;45:255-76.

32 Maisch B, Lotze U, Kochsiek K, Schneider J. Myocarditis and rheumatic fever predispose to cardiac conductio disturbances. An immunologic study. In: Belhassen B Feldman S, Copperman Y, eds. Cardiac pacing and electrophysiology. Proceedings of the VIIIth world symposium on cardiac pacing 1987. Tel Aviv: $R$ \& $\mathrm{L}$ Creative posimmications (Keterprises, Jerusalem) 1987. Creative

33 Ball J. Pathology and pathogenesis. In: Moll JMH, ed. Ankylosing spondylitis. Edinburgh, London, Melbourne, Ankylosing spondylitis. Edinburgh, London, Me

34 Woodrow JC. Genetics. In: Moll JMH, ed. Ankylosing spondylitis. Edinburgh, London, Melbourne, New York: spondylitis. Edinburgh, London, M
Churchill Livingstone, 1980:26-41.

35 Wright V. Relationships between ankylosing spondylitis and other spondarthritides. In: Moll JMH, ed. Ankylosing spondylitis. Edinburgh, London, Melbourne, New York: Churchill Livingstone, 1980:42-51.

36 Davidson P, Baggenstoss AH, Slocumb $\mathrm{CH}$ Daugherty GW. Cardiac and aortic lesions in rheumatoid spondylitis. Proc Staff Meet Mayo Clin 1963;38:427-35.

37 Bergfeldt L, Edhag O, Vallin H. Cardiac conduction disturbances, an underestimated manifestation in ankylosin spondylitis. A 25-year follow-up study of 68 patients. Acta Med Scand 1982;212:217-23. 